\title{
Bilim ve Sanat Merkezlerinde Görev Yapan Yönetici ve Öğretmenlerin Değer Tercihlerinin Farklı Değişkenler Açısından İncelenmesi
}

Evaluation of Value Preferences of Managers and Teachers Working in Science and Art Centers in Terms of Different Variables

Özge CEYLAN, Sorumlu Yazar. Öğretmen, Doktora öğrencisi. Kartal Bilim ve Sanat Merkezi. Yıldız Teknik Üniversitesi, Eğitim Fakültesi, Fen Bilimleri Eğitimi Bölümü.

E-mail: ozgeceylan86@gmail.com

ORCID: 0000-0003-3737-8579

Güven YILDIZ, Öğretmen.

Kartal Bilim ve Sanat Merkezi.

E-mail: guvenyildiz99@hotmail.com

ORGID: 0000-0001-7075-9838

ISSN: 1303-880X

e-ISSN: 2667-7504

http://ded.dem.org.tr

Geliş/Received: 10.10 .2018 Kabul/Accepted: 05.04.2019

Makale türü/Article type: Araştırma/Research
Atıf/Citation: Ceylan, Ö. \& Yıldız, G. (2019). Bilim ve Sanat Merkezlerinde görev yapan yönetici ve öğretmenlerin değer tercihlerinin farklı değişkenler açısından incelenmesi. Değerler Eğitimi Dergisi, 17 (37), 147-174. DOI: $10.34234 /$ ded. 469188 
Öz: Bu araştırmanın amacı bilim ve sanat merkezlerinde görev yapan yönetici ve öğretmenlerin değer tercihlerinin farklı değişkenler açısından incelenmesidir. Araştırmada model olarak ilişkisel tarama modeli kullanılmıştır. Veri toplama arac1 olarak Schwartz Değerler Ölçeği (SDÖ) ve kişisel bilgiler formu kullanılmıştır. Schwartz Değerler Ölçeği (SDÖ), Schwartz tarafindan 1992 yılında geliştirilmiş, Kuşdil ve Kağıtçıbaşı (2000) tarafından Türkçe'ye uyarlaması yapılmıştır. Araştırmanın evrenini tüm BILLSEM eğitimcileri, örneklemini ise basit seçkisiz örnekleme yöntemi ile seçilen 433 öğretmen ve 105 yönetici $(\mathrm{N}=538)$ oluşturmaktadır. Verilerin analizi SPSS paket programı 23. versiyonu ile yapılmıştır. Araştırmanın bulgularına göre ölçekte yer alan alt boyutların ortalama puanlarının çeşitli değişkenlere göre farklılaşması araştırılmıştır. BİLSEM kadın ve erkek eğitimcilerin ortalama puanları arasında "cinsiyet" değişkenine göre geleneksellik alt boyutunda; "görev" değişkenine göre güç, öz yönelim, evrensellik ve geleneksellik alt boyutlarında; "mesleki kıdem yıll”" değişkenine göre hazcılık alt boyutunda; "mezuniyet derecesi" değişkenine göre hazcılık ve geleneksellik alt boyutlarında farklılık ortaya çıkmıştır. Yaş değişkenine göre eğitimcilerin değer tercihlerinde bütün alt boyutlarda farklılık görülmemiştir Araştırmanın bulguları tartışma ve sonuç bölümünde yorumlanmıştır.

Anahtar Kelimeler: Üstün zekal1/yetenekli bireyler, Bilim ve sanat merkezi, Değer eğitimi

\section{$\&$}

Abstract: The aim of this study is to examine the value preferences of managers and teachers working in science and art centers in terms of different variables. Relational screening model was used as a model. Schwartz Values Scale and Personal Information Form were used as data collection tools. The Schwartz Values Scale (SVS) was developed by Schwartz in 1992 and adapted to Turkish by Kuşdil and Kağıtçıbaşı (2000). The sample of the study consisted of all BILSEM educators, and the sample was composed of 433 teachers and 105 managers $(\mathrm{N}=538)$ selected by simple random sampling method. Data analysis was done by SPSS software version 23. In the study, the differentiation of the mean scores of the sub-dimensions in the scale according to various variables was investigated. There was a difference between the mean scores of women and men educators according to sex variable in tradition sub-dimension. According to task variable, differences in power, self-direction, universalism and tradition sub-dimensions were observed. There was a difference in hedonism sub-dimension according to the variable of seniority year. According to the degree of 
graduation, there was a difference in hedonism and tradition sub-dimensions. According to the age variable, there was no difference in the value preferences of the educators in all sub-dimensions. The findings of the study were discussed in the discussion and conclusion section.

Keywords: Gifted / talented individuals, Science and art center, Value education

\section{Giriş}

İnsanlığın var oluş tarihi boyunca gelişimine bakıldığında öncelikle açlık, barınma, kendini savunma gibi hayatta kalmaya yönelik fiziksel ihtiyaçlarını giderdiği, daha sonra neslini devam ettirmeye çalıştığı ve daha iyi koşullarda yaşamak için her alanda ilerleme kaydettiği görülmektedir. Daha iyi şartlarda yaşama amacı ile gelecek nesle fiziksel ortam ile birlikte bir kültür mirası da bırakmıştır. Her toplumun kendine ait ekonomik, sosyal ve kültürel yapısı ve bu yapıları içeren değerleri vardır. Değer, Türk Dil Kurumu'nun güncel sözlüğünde "Bir şeyin önemini belirlemeye yarayan soyut ölçü", "Bir ulusun sahip olduğu sosyal, kültürel, ekonomik ve bilimsel değerlerini kapsayan maddi ve manevi öğelerin bütünü” olarak tanımlanmıştır. Spranger (1928) bireylerin sahip olduğu değerleri sosyal, ekonomik, bilimsel, estetik, dini ve politik olarak sınıflamıştır.

Bireylerin barış ve bütünlük içinde yaşayacağı daha iyi bir toplum için, yaşamlarında makul seviyede bir takım değerleri almalı ve o değerleri davranış ve tutumları ile sergilemelidir. Toplumsal hayatın devamını sağlayacak bireylerin yetiştirilmesi, okulların resmi görevleri arasında olduğu gibi bir taraftan da varl1k sebepleri olarak tanımlanabilir (Ekşi, 2003; Lickona, 1991; Ryan ve Bohin, 1991). Bu amaçla ataların yarattığı, biriktirdiği kültürel ve temel evrensel değerlerin her nesle öğretilmesinde değerler eğitimi kavramı ortaya çıkmaktadır. Birleşmiş Milletler Eğitim, Bilim ve Kültür Örgütü (UNESCO) tarafından değerler eğitimi "Çocukların ve gençlerin pozitif değerleri keşfedip geliştirmeleri ve kendi potansiyellerine göre ilerlemeleri için yürütülen eğitimsel gayretler" olarak tanımlamıştır.

Son yılarda özel sektör ve devlet politikası olarak üzerinde durulan ve önemli hale gelen bir kavram olan değerler eğitimi, eğitim bilimleri araştırmacılarını eğitimcilere ve öğrencilere hangi değerler öğretilmeli?, kullanılması gereken strateji ne olmalı?, değer öğretim süreci nasıl yürütülmeli? gibi sorulara cevap aramaya yöneltmiştir. İnsanlığın sahip olduğu temel evrensel değerler olduğu gibi her toplumun, her kurumun hatta her okulun kendi belirlediği değerler 
vardır. Değerlerden arınmış bir eğitim anlayışı düşünülemez (Taş ve Yeşiltaş, 2016). Okullarda çocukların ihtiyaçlarına göre değerler belirlenir ve onlara çeşitli şekillerde verilir. Okulda verilecek değerler eğitiminde sorumluluğu öğretmenler ve okul yöneticileri paylaşmaktadır. Aktay ve Ekşi (2009), okul yöneticilerinin ve öğretmenlerin sahip oldukları değerlerin, eğitim politikalarının ve felsefesinin belirlenmesi, bu politikaların programlar aracılı̆̆ıyla gerçekleştirilmeye çalışılması, personelin seçimi, geliştirilmesi ve değerlendirilmesi, kaynakların rasyonel kullanılması, sağlıklı bir okul kültürünün oluşturulması ve okulun etkili kılınmasında oldukça önemli bir yere sahip olduğunu ifade etmiştir. Yönetici ve öğretmenler öncelikle en iyi şekilde rol model olmalı, uygun değerler eğitimi koşullarını kurmalı, müdürler öğretmenleri programa uymaları bakımından denetlemeli ve veli ile iletişime geçerek temel değerleri kazandırma noktasında iş birliği içerisinde olmalıdır (Boydak Özan, 2009; Balyer, 2012; Özden, 2013). Yöneticiler tarafından değerler, büyük resmin şekillenmesinde, bütünleştirici bir vizyon ve amacın gelişmesinde, örgütlerine sağladıkları liderlik için daha güçlü araçlar arasında görülebilir (Yavuz, Dilmaç ve Derinbay, 2015). Okullarda kurum kültürünün oluşması bakımından bu bütünleştiricilik ve kurum yöneticilerinin değerlerin benimsenmesi, yaşatılması ve aktarılması karşısında takındığı tutum önemlidir. Aynı zamanda yöneticilerin sahip oldukları değerler ve bu değerlere dayalı yönetim uygulamaları; öğretmenlerle aralarındaki iş verimliliğini artırmada, öğretmenleri motive etmede, öğretmenlerin sayg1 gördükleri algısına sahip olmalarında önemli bir rol oynamaktadır (Demirtaş ve Ekmekyapar, 2012).

Değerler eğitimi okul öncesi dönemden itibaren başlar, ilk ve orta öğretim süresince eğitim öğretim programlarında doğrudan ya da örtük olarak yer alır. Yaşıtlarından bilişsel, duyuşsal ve psikomotor beceriler olarak ileri düzeyde olan üstün/özel yetenekli bireyler de bu eğitim sürecinden geçerler. Özel yetenekli bireyler topluma yön verecek, ülkeyi teknolojik, siyasi, ekonomik ve bilimsel anlamda güçlü kılacak yeteneğe sahip bir potansiyel olarak tanımlanmıştır (MEB, 2007). Bu özelliklere sahip çocuklar insanlık için büyük bir kazanım olacağı gibi eğitimlerinin önemsenmemesi ve potansiyellerinin dikkate alınmaması durumunda toplum için büyük bir kayıp olabilir (Kuzu ve Şenol, 2012). Beldağ ve Keskin (2016) çalışmalarında görüştükleri öğretmenlerin yarısı bilim ve sanat merkezlerinde uygulanan eğitim programlarının değerlerin kazanılmasında etkili olduğunu belirtirken, diğer yarısı ise etkili olmadığını belirtmişlerdir. Bu sebeple özel yetenekli bireylerin toplumun her alanda gelişimine sağlayacakları katkıların yanı sıra sahip oldukları değerler de önemli hale 
gelmektedir. Ülkemizde özel yetenekli bireylere bilim ve sanat merkezlerinde eğitim verilmektedir. Bilim ve sanat merkezleri (BİLSEM) özel yetenekli öğrencilere, özel yetenekli birey tanılaması yapıldıktan sonra, kendi okullarında aldıkları eğitime ek olarak yaşıtlarından ileri düzeyde eğitim-öğretim imkânı sağlayan kurumlardır. 2018-2019 eğitim öğretim y1lında özel yetenekli olduğu tanılanmış yaklaşık 42.000 öğrenciye 81 ilde 139 BILLSEM tarafından eğitim verilmektedir. BİLSEM'lerde çalışan yönetici ve öğretmenler özel yetenekli çocukların ihtiyaçlarına cevap verebilme yeterlilikleri bakımından, Milli Eğitim Bakanlığı Özel Eğitim ve Rehberlik Hizmetleri Daire Başkanlığı tarafindan oluşturulan komisyonlar tarafından çeşitli kriterlere göre değerlendirilerek görevlendirilirler. Bu kurumlarda çalışan öğretmen ve yöneticilerin akademik bakımdan yeterli, duyuşsal bakımdan gelişmiş olmaları beklenir. Çünkü evrensel ve toplumsal değerlerin kazandırılmasında diğer çocuklarda olduğu gibi özel yetenekli bireyler üzerinde de öğretmenlerin payı büyüktür. Öğretmenler değerleri kendi rollerinin bir parçası olarak göstermek istemeseler bile; öğrenciler, öğretmenlerinin değer yargılarından mutlaka etkilenirler (Halstead \& Taylor, 2000). Okul kültürünü yöneten ve denetleyen yöneticilerin öğretmen ve öğrencilerin üzerindeki etkisi yadsınamaz bir gerçektir. Bundan dolayı yönetici ve öğretmenlerin öncelikle bu değerlere sahip olması daha sonra değerleri öğrencilere rol model olarak ve eğitim yolu ile öğrencilere aktarması beklenir.

Bu çalışmanın amacı BILLSEM'lerde görev yapan yönetici ve öğretmenlerin değer tercihlerinin farklı değişkenler açısından incelenmesidir. Bu amaçla Schwartz Değerler Ölçeği kullanılmıştır. Ülkenin gelişiminde önemli bir potansiyele sahip özel yetenekli bireylerin akademik bilgileri kadar değerler alanında gelişmiş olmaları beklenir. Onları yetiştirecek eğitimcilerin evrensel değerlere ne derece sahip olup olmadıklarını ortaya çıkarmayı amaçlayan araştırma bu bakımdan önem kazanmaktadır. Öğretmen ve yöneticilerin sergiledikleri davranışlar ile sahip oldukları değerler arasındaki pozitif ilişkinin varlığı bilinmektedir. BILLSEM eğitimcilerinin benimsediği değerlerden kaynaklanan ilişkilerin kurumların yönetim politikalarını etkileyebileceği göz önünde bulundurulduğunda, araştırmada ortaya konulmaya çalış1lan BİLSEM öğretmen ve yöneticilerinin değer tercihlerinin özel eğitim alanında politika belirlenmesine, kaynakların verimli kullanılmasına, kurum kültürü oluşturulmasına fayda sağlayacağı düşünülmektedir. Önceki araştırmalarda yüksek öğretim, ortaöğretim, temel eğitim ve okul öncesi düzeyde görev yapan yönetici ve öğretmenlerin değer yargıları incelenmiş fakat özel yetenekli öğrencilere eğitim veren ve farklı bir eğitim öğretim programı olan BILSEM'lerde çalışan yönetici ve öğretmenlerin 
değer yargıları incelenmemiştir. Çalışma bu bakımdan da özgün bir nitelik kazanmaktadir.

Araştırmanın problemi "Bilim ve sanat merkezlerinde görev yapan yönetici ve öğretmenlerin değer tercihleri ile demografik özellikleri arasındaki ilişki nedir?" olarak belirlenmiştir. Bu probleme bağlı olarak aşağıda yer alan alt problemlere cevap aranmıştır.

Schwartz Değerler Ölçeği' inde yer alan alt boyutların ortalama puanları cintı siyet değişkenine göre farklılaşıyor mu?

Schwartz Değerler Ölçeği'inde yer alan alt boyutların ortalama puanları göy rev değişkenine göre farklılaşıyor mu?

Schwartz Değerler Ölçeği'inde yer alan alt boyutların ortalama puanları yaş değişkenine göre farklılaşıyor mu?

Schwartz Değerler Ölçeği'inde yer alan alt boyutların ortalama puanları mestı leki kıdem yılı değişkenine göre farklılaşıyor mu?

Schwartz Değerler Ölçeği' inde yer alan alt boyutların ortalama puanları mey zuniyet derecesi değişkenine göre farklılaşıyor mu?

\section{Yöntem}

Araştırmanın bu bölümünde araştırma modeli, çalışma grubu, veri toplama araçları ve verilerin analizi ile ilgili bilgiler yer alacaktır.

\section{Araştırma Modeli}

$\mathrm{Bu}$ araştırmada model olarak ilişkisel tarama modeli kullanılmıştır. İlişkisel tarama modeli; iki ya da daha çok sayıda değişken arasında birlikte değişim varlığını ve/veya derecesini belirlemeyi amaçlayan araştırma modelidir (Karasar, 2013).

\section{Çalışma Grubu}

Araştırmanın çalışma grubunu (N=538) Türkiye'de bulunan tüm BİLSEM'lerde görev alan yöneticiler (müdür ve müdür yardımc1sı) ve öğretmenlerden gönüllü olarak anket formunu dolduranlar oluşturmaktadır. Türkiye' de 2018-2019 eğitim öğretim yılında 139 BİLSEM faaliyet göstermektedir. Bu merkezlerde 139 müdür, 154 müdür yardımcısı ve yaklaşık 2100 öğretmen görev yapmak- 
tadır. Çalışmada kullanılan çevrimiçi anket formu, gerekli izinler alındıktan sonra, Türkiye'de bulunan tüm BİLSEM yönetici ve öğretmenlerine iletilmiş ve çevrim içi cevaplar toplanmıştır. Anketi, 105 yönetici ve 433 öğretmen yanıtlamıştır. Aşağıdaki tabloda anketi yanıtlayan kişilerin demografik özellikleri verilmiş̧ir.

\begin{tabular}{|c|c|c|c|}
\hline Özellik & Kategori & $\mathbf{N}$ & $\%$ \\
\hline \multirow{2}{*}{ Cinsiyet } & Kadın & 238 & 44,2 \\
\hline & Erkek & 300 & 55,8 \\
\hline \multirow{5}{*}{ Yaş } & $21-30$ & 60 & 11,2 \\
\hline & $31-40$ & 296 & 55 \\
\hline & $41-50$ & 155 & 28,8 \\
\hline & $51-60$ & 26 & 4,8 \\
\hline & $61+$ & 1 & 0,2 \\
\hline \multirow{2}{*}{ Görev } & Öğretmen & 433 & 80,5 \\
\hline & Yönetici & 105 & 19,5 \\
\hline \multirow{4}{*}{ Mesleki Kıdem Yılı } & 5 yildan az & 46 & 8,6 \\
\hline & $5-10 \mathrm{y} 11$ & 116 & 21,6 \\
\hline & $11-20$ y1l & 292 & 54,3 \\
\hline & $20+$ & 84 & 15,6 \\
\hline \multirow{3}{*}{ En Son Mezun Olunan Okul } & Lisans & 293 & 54,5 \\
\hline & Yüksek lisans & 227 & 42,2 \\
\hline & Doktora & 18 & 3,3 \\
\hline
\end{tabular}

Tablo 1 incelendiğinde ankete cevap veren eğitimcilerin $\% 55,8$ 'i erkek, $\% 44,2$ si kadındır. Katılımcıların yaş aralığı incelendiğinde ankete katılım büyük çoğunlukla \%55 oranla 31-40 yaş aralığındaki eğitimcilerden sağlanmıştır. Öğretmen ve yöneticiler arasında ise öğretmenlerin (\%80,5) yöneticilerden $(\% 19,5)$ dört kat daha fazla katılım sağladığı görülmüştür. Ankete katılan ve BİLSEM'lerde çalışan eğitimcilerin yarısından çoğunun (\%54,3) mesleki k1dem yılları 11-20 yıl aralığındadır. Eğitimcilerin en son mezun oldukları okul derecesi incelendiğinde lisans $(\% 54,5)$ ve yüksek lisans $(42,2)$ mezun sayılar1nın birbirine yakın olduğu, doktora (\%3.3) derecesinin ise çok az sayıda kişide olduğu ortaya çıkmıştır.

\section{Veri Toplama Araçları}

Araştırmada veri toplama aracı olarak Schwartz Değerler Ölçeği (SDÖ) ve kişisel bilgiler formu kullanılmıştır. Katılımcılardan kişisel bilgiler formunda cinsiyeti, yaşı, görevi, mesleki kıdem yılı ve mezuniyet bilgileri istenmiştir. 
Schwartz Değerler Ölçeği (SDÖ), Schwartz tarafından 1992 yılında geliştirilmiş, Kuşdil ve Kağıtçıbaşı (2000) tarafından Türkçe'ye uyarlaması yapılmıştır. Ölçek likert tipi bir ölçek olup, 57 madde ve on alt boyuttan oluşmaktadır (Schwartz ve Boehnke, 2004). Bu alt boyutlar güç, başarı, hazcılık, uyarılma, öz yönetim, evrensellik, yardimseverlik, geleneksellik, uyum ve güvenliktir. Bu alt boyutlar için güvenirlik katsayıları evrensellik .77, uyarılma .70, öz yönez tim.69, geleneksellik .63, yardımseverlik .76, hazcılık .54, güç .75, başarı .66, uyma .51 ve güvenlik .59 olarak bulunmuştur. Katılımcılardan kendileri için taş1dı̆̆g önem derecesine göre 1'den (ilkelerim ile ters düşmektedir) 7'ye (en üst düzeyde önemlidir) kadar puan vermeleri istenmiştir.

\section{Verilerin Analizi}

Verilerin analizi SPSS paket programı 23. versiyonu ile yapılmıştır. Öğretmen ve yöneticilerin Schwartz değerler ölçeğinden aldığı toplam puanların normal dağılım gösterdiği belirlenmiştir. Bu sebeple yöneticilerin ve öğretmenlerin Schwartz Değer Ölçeği'inde yer alan ana değer gruplarının demografik özelliklerine göre farkl1lığ incelemek için T- testi ve ANOVA uygulanmıştır.

\section{Bulgular}

\section{Birinci Alt Probleme Ait Bulgular}

Araştırmada ilk olarak "Schwartz Değerler Ölçeği' inde yer alan alt boyutların ortalama puanları cinsiyet değişkenine göre farklılaşıyor mu?" alt problemini cevaplamak amaciyla BİLSEM'lerde çalışan okul yönetici ve öğretmenlerine uygulanan SDÖ'ye ait alt boyutlardan alınan toplam puanların ortalamaları arasında cinsiyete göre farkın manidarlığını test etmek amacıyla bağımsız örneklemler için t- testi uygulanmış ve Tablo 2'de analiz sonuçları verilmiştir.

\begin{tabular}{|c|c|c|c|c|c|c|}
\hline Alt Boyut & Cinsiyet & $\mathbf{N}$ & $\overline{\mathbf{X}}$ & S.S & $\mathbf{t}$ & p \\
\hline \multirow{2}{*}{ Güvenlik } & Kadın & 238 & 44,36 & 4,644 & $-1,263$ & .105 \\
\hline & Erkek & 300 & 44,98 & 4,179 & & \\
\hline \multirow{2}{*}{ Güç } & Kadın & 238 & 24,48 & 5,277 & $-1,855$ & .064 \\
\hline & Erkek & 300 & 25,33 & 5,290 & & \\
\hline \multirow{2}{*}{ Başarı } & Kadın & 238 & 30,37 & 3,934 &,- 790 & .430 \\
\hline & Erkek & 300 & 30,65 & 4,010 & & \\
\hline \multirow{2}{*}{ Hazcılık } & Kadın & 238 & 16,68 & 3,100 &,- 725 & .469 \\
\hline & Erkek & 300 & 16,87 & 3,032 & & \\
\hline
\end{tabular}




\begin{tabular}{lcccccc}
\hline \multirow{2}{*}{ Uyarılma } & Kadın & 238 & 16,77 & 3,194 & $-1,618$ & .106 \\
\cline { 2 - 7 } & Erkek & 300 & 17,20 & 2,957 & & \\
\hline \multirow{2}{*}{ Ozz yönelim } & Kadın & 238 & 39,39 & 3,436 &, 565 & .572 \\
\cline { 2 - 7 } & Erkek & 300 & 39,21 & 3,604 & & \\
\hline \multirow{2}{*}{ Evrensellik } & Kadın & 238 & 59,42 & 5,221 &,- 150 & .881 \\
\cline { 2 - 7 } & Erkek & 300 & 59,49 & 5,492 & & \\
\hline \multirow{2}{*}{$\begin{array}{l}\text { Yardımse- } \\
\text { verlik }\end{array}$} & Kadın & 238 & 58,19 & 5,581 &,- 048 & .961 \\
\hline \multirow{2}{*}{ Geleneksellik } & Erkek & 300 & 58,22 & 5,558 & & \\
\cline { 2 - 7 } & Kadın & 238 & 34,57 & 5,077 & $-2,312$ &. $\mathbf{0 2 1}$ \\
\cline { 2 - 7 } Uyum & Erkek & 300 & 35,56 & 4,841 & & \\
\cline { 2 - 7 } & Kadın & 238 & 25,26 & 2,836 &,- 175 & .861 \\
\hline
\end{tabular}

Tablo 2 incelendiğinde BILLSEM kadın ve erkek eğitimcilerinin geleneksellik alt boyutuna ait puanları arasında anlamlı bir farklılık olduğu görülmektedir $(p=.021<.05)$. Grupların puan ortalamaları incelendiğinde erkek eğitimcilerin geleneksellik alt boyutuna ait puan ortalamaları $(\overline{\mathrm{X}}=35.56)$, kadın eğitimcilerin geleneksellik alt boyutuna ait puan ortalamalarından $(\overline{\mathrm{X}}=34.57)$ büyüktür.

\section{İkinci Alt Probleme Ait Bulgular}

Araştırmanın ikinci sorusu olan "Schwartz Değerler Ölçeği'inde yer alan alt boyutların ortalama puanları görev değişkenine göre farklılaşıyor mu?" alt problemini cevap vermek amacıyla, BİLSEM'lerde çalışan okul yönetici ve öğretmenlerine uygulanan SDÖ'ye ait alt boyutlardan alınan toplam puanların ortalamaları arasında eğitimcilerin görevlerine göre farkın manidarlığını test etmek amacıyla bağımsız örneklemler için t- testi uygulanmış ve Tablo 3'de analiz sonuçları verilmiştir.

Tablo 3: Değerler Ölçeğinde Yer Alan Alt Boyutların Ortalama Puanlarının Görev Değişkenine Göre Farklılaşmasının T- Test Sonuçları

\begin{tabular}{|c|c|c|c|c|c|c|}
\hline Alt Boyut & Görev & $\mathbf{N}$ & $\overline{\mathbf{X}}$ & S.S & $\mathbf{t}$ & $\mathbf{p}$ \\
\hline \multirow[t]{2}{*}{ Güvenlik } & Öğretmen & 433 & 44,85 & 4,408 & 1,515 & .130 \\
\hline & Yönetici & 105 & 44,12 & 4,325 & & \\
\hline \multirow[t]{2}{*}{ Güç } & Öğretmen & 433 & 24,48 & 5,263 & $-4,275$ & .000 \\
\hline & Yönetici & 105 & 26,90 & 5,001 & & \\
\hline \multirow[t]{2}{*}{ Başarı } & Öğretmen & 433 & 30,53 & 3,967 &, 034 & .973 \\
\hline & Yönetici & 105 & 30,51 & 4,027 & & \\
\hline \multirow[t]{2}{*}{ Hazcilık } & Öğretmen & 433 & 16,76 & 3,038 &,- 470 & .638 \\
\hline & Yönetici & 105 & 16,91 & 3,166 & & \\
\hline \multirow[t]{2}{*}{ Uyarılma } & Öğretmen & 433 & 16,96 & 3,154 &,- 767 & .444 \\
\hline & Yönetici & 105 & 17,22 & 2,693 & & \\
\hline \multirow[t]{2}{*}{ Öz yönelim } & Öğretmen & 433 & 39,55 & 3,459 & 3,566 & .000 \\
\hline & Yönetici & 105 & 38,20 & 3,620 & & \\
\hline
\end{tabular}




\begin{tabular}{lllllll}
\hline \multirow{2}{*}{ Evrensellik } & Öğretmen & 433 & 59,88 & 5,267 & 3,778 & $\mathbf{. 0 0 0}$ \\
\cline { 2 - 7 } & Yönetici & 105 & 57,70 & 5,452 & & \\
\hline \multirow{2}{*}{ Yardımseverlik } & Öğretmen & 433 & 58,40 & 5,606 & 1,658 & .098 \\
\cline { 2 - 7 } & Yönetici & 105 & 57,40 & 5,332 & & \\
\hline \multirow{2}{*}{ Geleneksellik } & Öğretmen & 433 & 34,83 & 5,129 & $-2,806$ &. $\mathbf{0 0 5}$ \\
\cline { 2 - 7 } & Yönetici & 105 & 36,33 & 4,028 & & \\
\hline \multirow{2}{*}{ Uyum } & Öğretmen & 433 & 25,40 & 2,887 & 1,965 & .050 \\
\cline { 2 - 7 } & Yönetici & 105 & 24,80 & 2,498 & & \\
\hline
\end{tabular}

Tablo 3 incelendiğinde ölçekte yer alan alt boyutlara ait toplam puanların ortalamaları arasında yönetici ve öğretmenler arasında güç alt boyutunda anlamlı bir farklılık görülmektedir $(\mathrm{p}=.000<.05)$. Grupların puan ortalamaları incelendiğinde yöneticilerim güç alt boyutuna ait puan ortalamaları $(\overline{\mathrm{X}}=26.90)$, öğretmenlerin güç alt boyutuna ait puan ortalamalarından $(\bar{X}=24.48)$ büyüktür. Ölçekte yer alan öz yönelim alt boyutuna ait puanların ortalamaları arasında anlamlı bir farklılık görülmektedir $(\mathrm{p}=.000<.05)$. Grupların puan ortalamala$\mathrm{r} 1$ incelendiğinde yöneticilerim öz yönelim alt boyutuna ait puan ortalamaları $(\bar{X}=38.20)$, öğretmenlerin öz yönelim alt boyutuna ait puan ortalamalarından $(\bar{X}=39.55)$ küçüktür. Ölçekte yer alan evrensellik alt boyutuna ait puanların ortalamaları arasında anlamlı bir farkl1lık görülmektedir $(\mathrm{p}=.000<.05)$. Grupların puan ortalamaları incelendiğinde yöneticilerim evrensellik alt boyutuna ait puan ortalamaları $(\overline{\mathrm{X}}=57.70)$, öğretmenlerin evrensellik alt boyutuna ait puan ortalamalarından $(\overline{\mathrm{X}}=59.88)$ küçüktür. Ölçekte yer alan diğer bir alt boyut olan geleneksellik alt boyutuna ait puanların ortalamaları arasında anlamlı bir farklılık görülmektedir $(\mathrm{p}=.005<.05)$. Grupların puan ortalamaları incelendiğinde yöneticilerim geleneksellik alt boyutuna ait puan ortalamaları ( $\overline{\mathrm{X}}=36.33)$, öğretmenlerin geleneksellik alt boyutuna ait puan ortalamalarından $(\overline{\mathrm{X}}=34.83)$ büyüktür.

\section{Üçüncü Alt Probleme Ait Bulgular}

Araştırmanın üçüncü alt problemi olan "Schwartz Değerler Ölçeği'inde yer alan alt boyutların ortalama puanları yaş değişkenine göre farklılaşıyor mu?" sorusuna cevap vermek amaciyla BİLSEM eğitimcilerine uygulanan SDÖ’ye ait alt boyutlardan alınan toplam puanların ortalamaları ile eğitimcilerin yaş aralıklarına göre farkın manidarlığını test etmek amacıyla bağımsız örneklemler için ANOVA (varyans analizi) uygulanmış ve Tablo 4'de analiz sonuçları verilmiştir. 


\begin{tabular}{|c|c|c|c|c|c|c|}
\hline Alt Boyut & Yaş & $\mathbf{N}$ & $\overline{\mathbf{X}}$ & S.S & $\mathbf{F}$ & $\mathbf{P}$ \\
\hline \multirow{4}{*}{ Güç } & $21-30$ & 60 & 24,47 & 5,990 & \multirow{4}{*}{.383} & \multirow{4}{*}{.765} \\
\hline & $31-40$ & 296 & 25,11 & 5,026 & & \\
\hline & $41-50$ & 155 & 24,76 & 5,635 & & \\
\hline & $51-60$ & 27 & 25,37 & 4,683 & & \\
\hline \multirow{4}{*}{ Başarı } & $21-30$ & 60 & 30,38 & 4,072 & \multirow{4}{*}{.053} & \multirow{4}{*}{.984} \\
\hline & $31-40$ & 296 & 30,52 & 3,918 & & \\
\hline & $41-50$ & 155 & 30,55 & 4,150 & & \\
\hline & $51-60$ & 27 & 30,74 & 3,537 & & \\
\hline \multirow{4}{*}{ Hazcilik } & $21-30$ & 60 & 17,33 & 2,589 & \multirow{4}{*}{1.528} & \multirow{4}{*}{.206} \\
\hline & $31-40$ & 296 & 16,84 & 3,159 & & \\
\hline & $41-50$ & 155 & 16,63 & 2,972 & & \\
\hline & $51-60$ & 27 & 15,93 & 3,339 & & \\
\hline \multirow{4}{*}{ Uyarılma } & $21-30$ & 60 & 16,77 & 3,642 & \multirow{4}{*}{.753} & \multirow{4}{*}{.521} \\
\hline & $31-40$ & 296 & 17,19 & 2,806 & & \\
\hline & $41-50$ & 155 & 16,81 & 3,287 & & \\
\hline & $51-60$ & 27 & 16,78 & 3,203 & & \\
\hline \multirow{4}{*}{ Öz yönelim } & $21-30$ & 60 & 16,77 & 2,907 & \multirow{4}{*}{.244} & \multirow{4}{*}{.866} \\
\hline & $31-40$ & 296 & 17,19 & 3,832 & & \\
\hline & $41-50$ & 155 & 16,81 & 3,294 & & \\
\hline & $51-60$ & 27 & 16,78 & 2,606 & & \\
\hline \multirow{4}{*}{ Evrensellik } & $21-30$ & 60 & 39,58 & 5,392 & \multirow{4}{*}{.092} & \multirow{4}{*}{.964} \\
\hline & $31-40$ & 296 & 39,24 & 5,639 & & \\
\hline & $41-50$ & 155 & 39,22 & 5,166 & & \\
\hline & $51-60$ & 27 & 39,59 & 3,183 & & \\
\hline \multirow{4}{*}{ Yardımseverlik } & $21-30$ & 60 & 58,80 & 4,922 & \multirow{4}{*}{.416} & \multirow{4}{*}{.742} \\
\hline & $31-40$ & 296 & 57,99 & 5,863 & & \\
\hline & $41-50$ & 155 & 58,35 & 5,396 & & \\
\hline & $51-60$ & 27 & 58,37 & 4,499 & & \\
\hline \multirow{4}{*}{ Geleneksellik } & $21-30$ & 60 & 34,17 & 5,447 & \multirow{4}{*}{2.123} & \multirow{4}{*}{.096} \\
\hline & $31-40$ & 296 & 34,89 & 5,031 & & \\
\hline & $41-50$ & 155 & 35,82 & 4,739 & & \\
\hline & $51-60$ & 27 & 35,74 & 3,986 & & \\
\hline \multirow{4}{*}{ Uyum } & $21-30$ & 60 & 25,40 & 2,650 & & \\
\hline & $31-40$ & 296 & 25,25 & 2,894 & 082 & 070 \\
\hline & $41-50$ & 155 & 25,33 & 2,733 & .002 & .910 \\
\hline & $51-60$ & 27 & 25,15 & 3,047 & & \\
\hline & $21-30$ & 60 & 44,08 & 4,515 & & \\
\hline Gürenlik & $31-40$ & 296 & 44,54 & 4,667 & 1240 & 205 \\
\hline Guvenlik & $41-50$ & 155 & 45,20 & 3,965 & 1,240 & .295 \\
\hline & $51-60$ & 27 & 45,04 & 3,180 & & \\
\hline
\end{tabular}

Tablo 4 incelendiğinde eğitimcilerin yaş aralıkları değişkeni ile ölçekte yer alan alt boyutlar arasında bir ilişki bulunamamıştır. Ortalamalar incelendiğinde her alt boyut için farklı yaş gruplarından eğitimcilerin puan ortalamalarının çok yakın olduğu görülmektedir. 


\section{Dördüncü Alt Probleme Ait Bulgular}

Araştırmanın dördüncü alt problemi olan "Schwartz Değerler Ölçeği'inde yer alan alt boyutların ortalama puanları mesleki kıdem yılı değişkenine göre farklılaşıyor mu?" sorusuna cevap vermek amacıyla BİLSEM eğitimcilerine uygulanan SDÖ’ye ait alt boyutlardan alınan toplam puanların ortalamaları ile eğitimcilerin kıdem yıllarına göre farkın manidarlığını test etmek amacıyla bağımsız örneklemler için ANOVA (varyans analizi) uygulanmış ve Tablo 5'te analiz sonuçları verilmiştir.

Tablo 5: Mesleki Kıdem Yılı Değişkeni ile Değerler Arasındaki ANOVA (varyans analizi) Sonuçları

\begin{tabular}{|c|c|c|c|c|c|c|}
\hline Alt Boyut & Mesleki kıdem Y1lı & $\mathrm{N}$ & $\bar{X}$ & S.S & $\mathrm{F}$ & $\mathrm{p}$ \\
\hline \multirow{4}{*}{ Güç } & 5 y1ldan az & 46 & 25,78 & 4,957 & \multirow{4}{*}{1.119} & \multirow{4}{*}{.341} \\
\hline & $5-10$ yil & 116 & 24,34 & 5,592 & & \\
\hline & $11-20 \mathrm{y} 1 \mathrm{l}$ & 292 & 25,15 & 5,272 & & \\
\hline & $20+$ & 84 & 24,67 & 5,123 & & \\
\hline \multirow{4}{*}{ Başarı } & 5 yildan az & 46 & 31,11 & 3,322 & \multirow{4}{*}{.817} & \multirow{4}{*}{.485} \\
\hline & $5-10$ y1l & 116 & 30,84 & 3,415 & & \\
\hline & $11-20 \mathrm{y} 11$ & 292 & 30,34 & 4,246 & & \\
\hline & $20+$ & 84 & 30,43 & 4,055 & & \\
\hline \multirow{4}{*}{ Hazcilık } & 5 yildan az & 46 & 17,85 & 2,607 & \multirow{4}{*}{3.339} & \multirow{4}{*}{.019} \\
\hline & $5-10$ y1l & 116 & 16,76 & 3,161 & & \\
\hline & $11-20$ y1l & 292 & 16,83 & 3,068 & & \\
\hline & $20+$ & 84 & 16,10 & 2,996 & & \\
\hline \multirow{4}{*}{ Uyarılma } & 5 yildan az & 46 & 17,30 & 3,265 & \multirow{4}{*}{1.150} & \multirow{4}{*}{.329} \\
\hline & $5-10$ yil & 116 & 17,20 & 3,014 & & \\
\hline & $11-20 \mathrm{y} 1 \mathrm{l}$ & 292 & 17,05 & 2,989 & & \\
\hline & $20+$ & 84 & 16,48 & 3,295 & & \\
\hline \multirow{4}{*}{ Öz yönelim } & 5 yildan az & 46 & 39,72 & 2,778 & \multirow{4}{*}{2.050} & \multirow{4}{*}{.106} \\
\hline & $5-10$ yil & 116 & 39,91 & 2,539 & & \\
\hline & $11-20$ y1l & 292 & 39,04 & 3,851 & & \\
\hline & $20+$ & 84 & 39,07 & 3,811 & & \\
\hline \multirow{4}{*}{ Evrensellik } & 5 yildan az & 46 & 59,22 & 5,481 & \multirow{4}{*}{.618} & \multirow{4}{*}{.604} \\
\hline & $5-10$ y1l & 116 & 59,79 & 4,209 & & \\
\hline & $11-20 \mathrm{y} 1 \mathrm{l}$ & 292 & 59,55 & 5,386 & & \\
\hline & $20+$ & 84 & 58,81 & 6,579 & & \\
\hline \multirow{4}{*}{ Yardımseverlik } & 5 yıldan az & 46 & 58,91 & 4,386 & \multirow{4}{*}{-1.231} & \multirow{4}{*}{.298} \\
\hline & $5-10$ y1l & 116 & 58,87 & 4,432 & & \\
\hline & $11-20 \mathrm{y} 1 \mathrm{l}$ & 292 & 57,99 & 5,960 & & \\
\hline & $20+$ & 84 & 57,64 & 6,053 & & \\
\hline \multirow{4}{*}{ Geleneksellik } & 5 yildan az & 46 & 34,57 & 5,231 & \multirow{4}{*}{.460} & \multirow{4}{*}{.710} \\
\hline & $5-10$ yil & 116 & 34,93 & 4,840 & & \\
\hline & $11-20 \mathrm{y} 1 \mathrm{l}$ & 292 & 35,16 & 5,035 & & \\
\hline & $20+$ & 84 & 35,55 & 4,796 & & \\
\hline
\end{tabular}




\begin{tabular}{|c|c|c|c|c|c|c|}
\hline \multirow{4}{*}{ Uyum } & 5 yıldan az & 46 & 25,22 & 2,715 & \multirow{4}{*}{.265} & \multirow{4}{*}{.851} \\
\hline & $5-10$ y1l & 116 & 25,47 & 2,479 & & \\
\hline & $11-20$ yil & 292 & 25,27 & 2,995 & & \\
\hline & $20+$ & 84 & 25,12 & 2,744 & & \\
\hline \multirow{4}{*}{ Güvenlik } & 5 yildan az & 46 & 43,70 & 5,120 & \multirow{4}{*}{1.049} & \multirow{4}{*}{.370} \\
\hline & $5-10$ y1l & 116 & 45,04 & 3,708 & & \\
\hline & $11-20$ yil & 292 & 44,71 & 4,582 & & \\
\hline & $20+$ & 84 & 44,80 & 4,182 & & \\
\hline
\end{tabular}

Tablo 5 incelendiğinde eğitimcilerin mesleki kıdem yılları ile ölçekte yer alan değerlerin alt boyutlarından alınan puan ortalamaları arasındaki fark görülmektedir. Eğitimcilerin alt boyutlara ait puan ortalamaları ile mesleki kıdem yıllarına göre farklılaşma yalnızca hazcılık alt boyutunda ortaya çıkmıştır $(\mathrm{p}=.019<.05)$. $\mathrm{Bu}$ farkın hangi gruplar arasında olduğunu belirlemek amacıyla Post Hoc Tukey HSD testi yapılmış ve analiz sonucuna göre hazcılık boyutunda 5 yıldan az k1deme sahip olanlar ile 20 yıldan fazla kıdeme sahip olanlar arasında anlamlı bir farklılık görülmüştür $(\mathrm{p}=.010<.05)$. Tabloda grup ortalamalarına bakıldığında ise 5 yıldan az kıdeme sahip olanların puan ortalamalarının diğerlerinden daha fazla olduğu görülmektedir $(\overline{\mathrm{X}}=17,85)$.

\section{Beşinci Alt Probleme Ait Bulgular}

Araştırmanın beşinci alt problemi olan 'Schwartz Değerler Ölçeği' inde yer alan alt boyutların ortalama puanları mezuniyet derecesi değişkenine göre farklılaşıyor mu?" sorusuna cevap vermek amacıyla araştırma grubunu oluşturan BİLSEM'lerde çalışan eğitimcilerin en son mezun oldukları okullar ile ölçeğe ait alt boyutlardan alınan toplam puan ortalamalarına göre farkın manidarlığını test etmek amacıyla bağımsız örneklemler için ANOVA (varyans analizi) uygulanmış ve Tablo 6'da analiz sonuçları verilmiştir.

\begin{tabular}{|c|c|c|c|c|c|c|}
\hline Alt Boyut & Mezuniyet Derecesi & $\mathrm{N}$ & $\overline{\mathrm{X}}$ & S.S & $\mathrm{F}$ & $\mathrm{p}$ \\
\hline \multirow{3}{*}{ Güç } & Lisans & 293 & 25,34 & 5,079 & \multirow{3}{*}{1.864} & \multirow{3}{*}{.156} \\
\hline & Yüksek Lisans & 227 & 24,44 & 5,518 & & \\
\hline & Doktora & 18 & 25,11 & 5,656 & & \\
\hline \multirow{3}{*}{ Başarı } & Lisans & 293 & 30,81 & 3,728 & \multirow{3}{*}{1.633} & \multirow{3}{*}{196} \\
\hline & Yüksek Lisans & 227 & 30,19 & 4,173 & & \\
\hline & Doktora & 18 & 30,17 & 5,090 & & \\
\hline \multirow{3}{*}{ Hazcılık } & Lisans & 293 & 17,11 & 2,932 & \multirow{3}{*}{3.824} & \multirow{3}{*}{.022} \\
\hline & Yüksek Lisans & 227 & 16,37 & 3,144 & & \\
\hline & Doktora & 18 & 16,89 & 3,563 & & \\
\hline
\end{tabular}




\begin{tabular}{|c|c|c|c|c|c|c|}
\hline \multirow{3}{*}{ Uyarılma } & Lisans & 293 & 17,24 & 3,025 & \multirow{3}{*}{1.790} & \multirow{3}{*}{.168} \\
\hline & Yüksek Lisans & 227 & 16,73 & 3,150 & & \\
\hline & Doktora & 18 & 16,94 & 2,532 & & \\
\hline \multirow{3}{*}{ Öz yönelim } & Lisans & 293 & 39,31 & 3,496 & \multirow{3}{*}{.022} & \multirow{3}{*}{.978} \\
\hline & Yüksek Lisans & 227 & 39,27 & 3,444 & & \\
\hline & Doktora & 18 & 39,17 & 5,067 & & \\
\hline \multirow{3}{*}{ Evrensellik } & Lisans & 293 & 59,63 & 5,180 & \multirow{2}{*}{.678} & \multirow{2}{*}{.508} \\
\hline & Yüksek Lisans & 227 & 59,34 & 5,211 & & \\
\hline & Doktora & 18 & 58,22 & 9,29 & & \\
\hline \multirow{3}{*}{ Yardımseverlik } & Lisans & 293 & 58,41 & 5,467 & \multirow{3}{*}{.467} & \multirow{3}{*}{.627} \\
\hline & Yüksek Lisans & 227 & 57,99 & 5,434 & & \\
\hline & Doktora & 18 & 57,61 & 8,354 & & \\
\hline \multirow{3}{*}{ Geleneksellik } & Lisans & 293 & 35,63 & 4,971 & \multirow{3}{*}{3.433} & \multirow{3}{*}{.033} \\
\hline & Yüksek Lisans & 227 & 34,52 & 4,833 & & \\
\hline & Doktora & 18 & 34,44 & 5,853 & & \\
\hline \multirow{3}{*}{ Uyum } & Lisans & 293 & 25,42 & 2,693 & \multirow{3}{*}{.990} & \multirow{3}{*}{.372} \\
\hline & Yüksek Lisans & 227 & 25,09 & 2,924 & & \\
\hline & Doktora & 18 & 25,61 & 3,550 & & \\
\hline \multirow{3}{*}{ Güvenlik } & Lisans & 293 & 44,93 & 4,433 & \multirow{3}{*}{.833} & \multirow{3}{*}{.435} \\
\hline & Yüksek Lisans & 227 & 44,45 & 4,221 & & \\
\hline & Doktora & 18 & 44,28 & 5,869 & & \\
\hline
\end{tabular}

Tablo 6 incelediğinde BİLSEM eğitimcilerinin en son mezuniyet dereceleri ile değerler ölçeğinde yer alan alt boyutlara ait puan ortalamaları arasındaki farka ait analiz sonuçları görülmektedir. Bu sonuçlara göre hazcıllk alt boyutu puan ortalamaları ile mezuniyet dereceleri arasında farklılık ortaya çıkmıştır $(\mathrm{p}=.022<.05) . \mathrm{Bu}$ farkın hangi gruplar arasında olduğunu belirlemek amaciyla Post Hoc Tukey HSD testi yapılmış ve analiz sonucuna göre hazcılık boyutunda lisans mezunu olanlar ile yüksek lisans mezunu olanlar arasında anlamlı bir farkl1lık görülmüştür $(\mathrm{p}=.016<.05)$. Tabloda grup ortalamalarına bakıldığında ise lisans mezunu olanların puan ortalamalarının diğerlerinden daha fazla olduğu görülmektedir ( $\bar{X}=17,11)$. Eğitimcilerin mezuniyet dereceleri ile ölçekte yer alan alt boyutlara ait puan ortalamaları arasında geleneksellik alt boyutunda anlamlı bir farklılık ortaya çıkmıştır $(\mathrm{p}=.033<.05)$. Bu farkın hangi gruplar arasında olduğunu belirlemek amacıyla Post Hoc Tukey HSD testi yapılmış ve analiz sonucuna göre geleneksellik alt boyutunda lisans mezunu olanlar ile yüksek lisans mezunu olanlar arasında anlamlı bir farklılık görülmüştür $(\mathrm{p}=.029<.05)$. Tabloda grup ortalamalarına bakıldığında ise lisans mezunu olanların puan ortalamalarının diğerlerinden daha fazla olduğu görülmektedir $(\overline{\mathrm{X}}=35,63)$. 


\section{Tartışma ve Sonuç}

Rokeach'in (1973) değer listesi üzerinden oluşturulan Schwartz ve Bilsky (1987) değer listesi Schwartz (1992) değer yaklaşımının temelini oluşturmaktadır. Araştırmanın sonuçları Schwartz değer yaklaşımı temelinde tartışılmıştır.

Araştırmanın birinci probleminde ölçekte yer alan alt boyutların ortalama puanlarının "cinsiyet" değişkenine göre farklılaşması araştırılmış ve BíLSEM kadın ile erkek eğitimcilerin ortalama puanları arasında geleneksellik alt boyutunda farklılık ortaya çıkmıştır. Bu farklılığın erkek eğitimcilerin lehine olduğu görülmektedir yani erkek eğitimcilerin kadın eğitimcilerden geleneksel değerlere daha fazla sahip olduğu söylenebilir. "Geleneksellik", sosyokültürel yapı ve din ile birlikte düşünce ve yaşam tarzlarının benimsenmesiyle ilişkilidir (Akdeniz, 2018). Toplumsal kurallara itaati gereklilik olarak gören geleneksellik, soyut olan dini kurallara, kültürel adet ve fikirlere itaati öngörmektedir. Bu durumda erkek eğitimcilerin kadınlara göre soyut kavramlara daha itaatkar oldukları ifade edilebilir. Erkeklerin lehine geleneksellik boyutunda farklılık çıkması ise toplumun erkeğe biçtiği rol ile ilişkili olabilir. Sığrı, Tabak ve Ercan (2009) araştırmalarında erkek bankacıların kadınlara göre geleneksel değerlerine bağlı olduklarını ortaya çıkarmışlardır. Yavuz, Dilmaç ve Derinbay (2015) yöneticiler ile yaptıkları çalışmada benzer bir sonuca ulaşmışlardır. Bunun yanında kadın yöneticilerin uyum alt boyutunda erkek yöneticilerden farklılık gösterdiği ve bu farklılığın kadınların lehine olduğunu ifade etmişlerdir. Yılmaz'ın (2009) öğretmenler ile yaptığı araştırma da kadın öğretmenlerin evrensellik, yardımseverlik, uyum ve güvenlik boyutlarının puan ortalamasının erkeklerden farklı olduğunu göstermiş̧tir. Sarı (2005) ise yaptığı araştırmada tüm alt boyutlarda erkeklerin ortalama puanlarının kadınların puanlarından yüksek olduğunu ortaya çıkarmıştır. Tanıt (2007), İmamoğlu ve Aygün- Karakitaboğlu (1999) çalışmalarında kadın ve erkeklerin değer alt boyutları arasında farklılık yoktur bulgusuna ulaşmıştır, buna karşı ise bir çok çalışma cinsiyet faktörünün değer farklılaşmasında etkili olduğunu ortaya koymuştur (Bacanlı, 1999; Demirutku, 2007; Kuzgun ve Sevim, 2004; Acar, Yıldırım ve Ergene, 1996). Bu araştırmada BİLSEM eğitimcilerinin cinsiyet faktörü bakımından yalnızca geleneksellik alt boyutunda farklılık çıkması ve diğer boyutlarda farklı1ık olmaması; geçmiş yıllarda yapılan araştırmalardan da yola çıkarak zaman içerisinde toplumumuzda oluşan cinsiyet eşitliği, her bireye kazandırılması gereken temel değerlerin olması gerektiği, kadın ve erkeğin toplumda paylaştığı rollerin farklılaşması, son yıllarda müfredata daha fazla dahil edilen değerler eğitimi gibi faktörlerden kaynaklanabilir. Ayrıca erkek eğitimcilerin kadın eğitimcilere göre kültürel 
veya dini gelenek ve düşüncelere daha fazla bağlı olduğu, buna bağlı olarak erkek yönetici sayısının ülkemizde fazla olduğu göz önünde bulundurulduğunda okullarda sürdürülen yönetim anlayışının daha çok geleneksel değerlere dayalı olarak yürütülebileceği yorumu yapıllabilir.

Araştırmanın ikinci probleminde ölçekte yer alan alt boyutların ortalama puanlarının "görev" değişkenine göre farklılaşması araştırılmış, BILLSEM yönetici (müdür ve müdür yardımcısı) ve öğretmenlerinin ortalama puanları arasında güç, öz yönelim, evrensellik ve geleneksellik alt boyutlarında farklılık ortaya çıkmıştır. Bu farklılaşmanın güç ve geleneksellik alt boyutunda yöneticilerin lehine, öz yönelim ve evrensellik alt boyutunda ise öğretmenlerin lehine olduğu görülmektedir. Geleneksellik alt boyutu dini kurallara, kültürel adet ve fikirlere itaati gerektirirken, güç alt boyutu ise denetim sağlama, statü ve itibar elde etmeyi vurgulayan bir boyuttur. Bu durum BILSEM yöneticilerinin toplumsal kurallar ile birlikte denetim, statü ve itibara önem verdikleri; insanlar ve kaynakları kontrol etme, onlar üzerinde hâkimiyet kurma gibi eğilimlerinin olduğu yorumu yapılabilir. Kuşdil ve Kağıtçıbaşı'nın (2000) çalışmasına göre bu sonuç yöneticiler için gücün başkalarının zararına bile olsa kendi çıkarları doğrultusunda kullanılmasına olanak sağlayabilir şeklinde yorumlanabilir. BİLSEM öğretmenlerinin puan ortalamalarının öz yönelim alt boyutunda yöneticilerden daha fazla çıkması onların bağımsız düşünce ve davranışla özdeşleşen bir anlayışa sahip olduklarını gösterir. Evrensellik alt boyutunda yöneticilerden fazla çıkması ise anlayışlı ve hoşgörü olma, takdir edebilme, doğayı koruma ve tüm insanlığın iyiliğini isteme gibi yönelimleri olduğunu yorumu yapılabilir. Bu bulguların aksine Yavuz, Dilmaç ve Derinbay (2015) ve Şahin- Firat (2010) çalışmalarında görev değişkenine göre hazcılık alt boyutunda farklılaşma ortaya çıkarmışlar, öğretmenlerin ortalama puanlarının daha yüksek olduğunu ifade etmişlerdir. Aktay ve Ekşi (2009) çalışmalarında görev değişkenine göre alt boyutlarda herhangi bir farklılaşma bulamamışlardır. Uncu (2008) öğretmen ve yöneticiler ile yaptığ önemli bir farklılık olmadığını, en çok tercih edilen değerin evrensellik, en az tercih edilen değerin güç olduğunu ifade etmiştir. BİLSEM öğretmen ve yöneticilerinin değer tercihlerinde ortaya çıkan farklılı̆̆ın özel yetenekli bireyler üzerindeki yansıması düşünüldüğünde, öğrencilerin bağımsız düşünen, hoşgörülü ve tüm insanlığın iyiliğine çalışan öğretmenler tarafından yetiştirileceği fakat öğretmenlerinin ise daha geleneksel bir anlayışla yönetilen okullarda çalışacağ yorumu yapılabilir. Bu durum öğretmen ve idareci arasında uyumsuzluğa sebep olabilir ve bu da iş performansına ve mesleki doyuma etki edebilir. Çalışanların zaman zaman zorluklarla karşılaşmalarının başka bir nedeni de bazı durum- 
larda çalışanların değer sistemleri ile örgütün değer sistemlerinin uyuşmaması olmaktadır (Turgut, 1998:44). BİLSEM'lerde hedeflenen kurumsallaşmanın sağlanması ve başarıya ulaşılması amaciyla yönetici ve öğretmenlerin ortak değerlere sahip olması bu açılardan önemli hale gelmektedir.

Araştırmanın üçüncü alt probleminde ölçekte yer alan alt boyutların ortalama puanlarının "yaş" değişkenine göre farklılaşması araştırılmış eğitimcilerin yaş aralıkları değişkeni ile alt boyutlar arasında bir ilişki bulunamamıştır. Ortalamalar incelendiğinde her alt boyut için eğitimcilerin puan ortalamalarının çok yakın olduğu bulunmuştur. Buna benzer olarak Aktay ve Ekşi (2009) çalışmalarında yaş değişkenine göre alt boyutlarda herhangi bir farklılaşma bulamamışlardır. Fırat ve Açıkgöz (2012) çalışmalarında başarı, uyarılım ve uyma değer boyutlarında yaş değişkeninin önemli bir belirleyici olduğunu, genç yaş grubunda başarı, 40 yaş ve daha gençlerde uyarılım ve 40 yaşından büyük grupta ise uyma boyutunda farkl1l1k olduğunu ifade etmişlerdir. Bu araştırmada yaş değişkenine bağlı değerlerde farklılık ortaya çıkmaması ile ilgili olarak BİLSEM'de çalışan eğitimcilerin kuşaklar arasındaki değer farklılığının oluşmad1$\breve{g} 1$, ortak bir düşünceye sahip oldukları yönünde açılanabilir. Bu da bir toplumun sahip olduğu değerlerin zaman içerisinde hızlı bir değişime uğramadığının göstergesi sayılabilir.

Araştırmanın dördüncü alt probleminde ölçekte yer alan alt boyutların ortalama puanlarının "mesleki kıdem yılı" değişkenine göre farklılaşması araştırılmış, yalnızca hazcılık alt boyutunda farklılık ortaya çıkmıştır. Bu farklılığın ise 5 yıldan az kıdeme sahip olanlar ile 20 yıldan fazla kıdeme sahip olanlar arasında olduğu ve puan ortalamasının ise 5 yıldan az olanların lehine olduğu belirlenmiştir. "Hazcılık" alt boyutu kişinin biyolojik ihtiyaçlarını ve memnuniyet duygusunu kapsar. Kıdemi 5 yıldan az olanların 21-30 yaş aralığına denk geldiği düşünüldüğünde, genç öğretmen neslinin 40 ve üzeri yaş grubundaki öğretmenlere göre daha çok fiziksel ihtiyaçlarını doyurmaya yönelik değer yönelimleri olduğu ifade edilebilir. Bu durumun da yeni neslin tüketim alışkanlıkları ile ve daha çok bireysel ihtiyaçlarını karşılamaya, bireysel mutluluğa yönelik hayat yaşama eğilimleri ile ilişkili olduğu yorumu yapılabilir. Buna benzer olarak Işık ve Yıldız (2012) tarafından yapılan çalışmada ise öğretmenlerin mesleki deneyimlerinin ilk yıllarında hazcılık temel değerine daha çok önem verdiği sonucuna ulaşılmıştır. Yavuz, Dilmaç ve Derinbay (2015) çalışmalarında eğitimcilerin kıdem değişkenine göre uyarılma ve özyönetim boyutlarında farklılık bulmuşlardır ve bu farklılığın 10-14 yıl kıdeme sahip olan gruptan kaynaklandığını ifade etmişlerdir. Yılmaz (2009) öğretmenlerin değer tercihlerinin 
1-5 yı1 arası kıdeme sahip olanların güç boyutunda, 11-20 arası kıdeme sahip olanların geleneksellik boyutunda, 21 yıl ve üstü kıdeme sahip olanların uyarılma boyutunda farklılık gösterdiğini araştırmasında ortaya koymuştur. Aktay (2008) ve Tanıt (2007) ise öğretmen ve yöneticilerde kıdem değişkenine göre değer tercih boyutlarında bir farklılık bulamamışlardır.

Araştırmanın beşinci alt probleminde ölçekte yer alan alt boyutların ortalama puanları "mezuniyet derecesi" değişkenine göre farklılaşması araştırılmış, hazcılık ve geleneksellik alt boyutlarında farklılık ortaya çıkmıştır. Bu farklılık lisans ve yüksek lisans derecelerine sahip olanlar arasında ve lisans mezunu olanların lehine bulunmuştur. Aktay ve Ekşi (2009) eğitim durumlarına göre güç, hazcılık, başarı, uyarılma, geleneksellik alt boyutlarında herhangi bir farklılaşma bulamamışlar fakat öz denetim, evrensellik, yardımseverlik, uyum ve güvenlik alt boyutlarında farklılaşmakta olduğunu öne sürmüşlerdir. Yavuz, Dilmaç ve Derinbay (2015) okul müdürlerinin değerlerinin öğrenim durumlarına göre güç, uyarılma ve güvenlik boyutlarında farklılaştığını bunun ile birlikte müdürlerden lisans mezunu olanların puan ortalamalarının ön lisans mezunu olanlardan fazla olduğunu belirtmişlerdir. BİLSEM eğitimcilerinden lisans mezunu olanların hazcılık ve geleneksellik alt boyut puanlarının yüksek çıkması, akademik olarak öğretmenlik mesleğinde en alt eğitim seviyesinde olan grupların daha çok dini kurallara, kültürel adet ve fikirlere itaatkar olduklarını fakat beklenmedik bir şekilde biyolojik mutluluk ve hazza da aynı oranda önem verdiklerini ortaya çıkarmıştır. Eğitimcilerin akademik seviyeleri arttıkça geleneksel yapıdan uzaklaşıp uzaklaşmadıkları incelenmesi gereken bir konu olmakla birlikte mezuniyet derecesinin onların değer tercihlerine etki etmesi önemli bir sonuçtur.

Araştırmanın önerileri ise şu şekilde sıralanabilir;

- $\mathrm{Bu}$ araştırmanın bulgularında BİLSEM yönetici ve öğretmenlerinin değer tercihleri incelenmiş, velilerinin değer tercihlerine yer verilmemiştir. Berkant, Efendioğlu ve Sürmeli (2014) çalışmalarında öğretmenlerin değerler eğitiminde ailenin rolünün büyük olduğu bu sebeple bilinçli ailelerin önemini ifade etmişlerdir. $\mathrm{Bu}$ açıdan aileler ile değerlere yönelik bir araştırma yapılabilir, ardından araştırma çeşitli eğitimler ile desteklenebilir.

- Araştırmada yönetici ve öğretmenlerin değer tercihleri arasında farklılıklar ortaya çıkmıştır. BILLSEM yönetici ve öğretmenlerine, öğrencilerin de ihtiyaçlarını dikkate alarak, çalışmalarda değer farklılıklarını en az seviyeye indirecek şekilde bir değerler eğitimi semineri ya da hizmet içi eğitimi düzenlenebilir. 
- Araştırma belirli demografik özellikler üzerinden yürütülmüştür. Bunlara ek olarak medeni durumu, gelir seviyesi, çocuk sahibi olup olmadığı ya da hangi kültürde yetiştiği gibi farklı özellikler de eklenerek yeniden yorumlanabilir. Bir çok araştırma kültürün, medeni durumun değer tercihlerinde etkili olduğunu ifade etmektedir, BİLSEM eğitimcilerinde de bu durumun analizi yap1labilir.

- Bu araştırmada yalnızca değer tercihleri ve demografik özellikler arasındaki ilişki incelenmiştir. Sonraki çalışmalarda BILLSEM yönetici ve öğretmenlerinin değerleri ile örgütsel değerler, örgütsel vatandaşl1k arasında ilişkisel bir araştırma yapılabilir.

- Araştırmada en fazla farklılık yönetici ve öğretmenlerin değerlerinde ortaya çıkmıştır. Bu durumun en aza indirgenmesi için öncelikle öğretmen ya da müdürlerin BİLSEM'de çalışmanın amaçlarına yönelik düşünceleri nitel bir çalışma ile belirlenebilir ve bu amaçlar ortak bir paydada değerler ile bütünleştirilerek yönetici ve öğretmenlere verilebilir.

- Araştırmada öğretmen ve yöneticilerin değer tercihlerinde ortaya çıkan farklılıkların, onların çalışma ortamlarına ve iş performanslarına etkisi olup olmadığı araştırılabilir.

\section{Kaynakça}

Acar, N. V., Yıldırım, İ., \& Ergene, T. (1996). Bireylerin dindarlık düzeylerinin bazı değiş̧kenler açısından incelenmesi. Hacettepe Üniversitesi Eğitim Fakültesi Dergisi, 12(12), 45-56.

Akdeniz, A. (2018). Sosyal Bilgiler ve tarih ögrretmenlerinin yurtseverlik tutumlarl ile temel değer yönelimleri arasındaki ilişki. Yayımlanmamış yüksek lisans tezi. Tokat Gaziosmanpaşa Üniversitesi, Eğitim Bilimleri Enstitüsü.

Aktay, A. (2008). Yönetici ve ögretmenlerin değer tercihleri ile örgütsel vatandaşllk davranışları arasındaki ilişkinin incelenmesi. Yayımlanmamış yüksek lisans tezi. Yeditepe Üniversitesi Sosyal Bilimler Enstitüsü.

Aktay, A. \& Ekşi, H. (2009). Yönetici ve öğretmenlerin değer tercihleri ile örgütsel vatandaşlık davranışları arasındaki ilişki. İş Ahlakı Dergisi, 2(3), 19-65.

Bacanl, H. (1999). Üniversite öğrencilerinin değer tercihleri. Kuram ve Uygulamada Eğitim Yönetimi Dergisi, 5(4), 597-610.

Balyer, A. (2012). Çağdaş okul müdürlerinin değişen rolleri. Ahi Evran Üniversitesi Kırşehir Eğitim Fakültesi Dergisi (KEFAD), 13(2), 75-93. 
Beldağ, A., \& Keskin, S. (2016). Bilim ve sanat merkezlerinde ve diğer okullarda öğrenim gören öğrencilerin sahip oldukları değerlere ilişkin öğretmen görüşleri. Kırıkkale Üniversitesi Sosyal Bilimler Dergisi, 6(1), 9-24.

Berkant, H. G., Efendioğlu, A., \& Sürmeli, Z. (2014). Değerler eğitimine yönelik öğretmen görüşlerinin incelenmesi. Electronic Turkish Studies, 9(5), 427-440.

Boydak Özan, M. (2009). Öğrenim görülen okul türüne göre yöneticilerin öğrencilere değer kazandırma davranışları. Doğu Anadolu Bölgesi Araştırmaları Dergisi, 8(1), 55-62.

Demirtaş, Z. \& Ekmekyapar, M. (2012). İlköğretim okulu yöneticilerinin değerlere dayalı yönetim uygulamalarının okul kültürüne etkisi. Kuram ve Uygulamada Eğitim Yönetimi [Educational Administration: Theory And Practice], 18(4), 523- 544.

Demirutku, K. (2007). Parenting styles, internalization of values, and the self-concept [çocuk yetiştirme tarzları, değerler içselleştirilmesi ve benlik kavramı]. Yayınlanmamış doktora tezi. Orta Doğu Teknik Üniversitesi.

Ekşi, H . (2003). Temel insanî değerlerin kazandırılmasında bir yaklaşım: karakter eğitimi programları. Değerler Eğitimi Dergisi, 1(1), 79-96.

Fırat, N. Ş., \& Açıkgöz, K. (2012). Bazı değişkenler açısından öğretmenlerin değer sistemleri. Hacettepe Üniversitesi Eğitim Fakültesi Dergisi, 43, 422-435.

Halstead, J. M., \& Taylor, J. M. (2000). Learning and teaching about values: a review of recent research. Cambridge Journal of Education , 30(2),169-202.

Işık, N \& Yıldız, N. (2012). İlköğretim sınıf öğretmenlerinin değer algıları ile kişilerarası problem çözme becerileri arasındaki ilişkinin değerlendirilmesi. Social Science Studies, 2(3),1-16.

İmamoğlu, E. O. \& Karakitapoğlu Aygün, Z. (1999). 1970’lerden 1990'lara değerler: Üniversite düzeyinde gözlenen zaman, kuşak ve cinsiyet farklılıklar1. Türk Psikoloji Dergisi, 14(44), 1-22.

Karasar, N. (2013). Bilimsel araştırma yöntemi. Ankara: Nobel Yayın Dağıtım.

Kuşdil, M. E. \& Kağıtçıbaşı, Ç. (2000). Türk öğretmenlerinin değer yönelimleri ve schwartz değer kuramı. Türk Psikoloji Dergisi, 45, 59-76.

Kuzgun, Y., \& Sevim, S. A. (2004). Kadınların çalışmasına karşı tutum ve dini yönelim arasındaki ilişki. Ankara Üniversitesi Eğitim Bilimleri Fakültesi Dergisi, 37(1), 14-27.

Kuzu, İ. Y. \& Şenol, C. (2012). Üstün yetenekliler eğitim programlarına ilişkin öğretmen görüşleri (BİLSEM Örneği). E-Uluslararası Eğitim Araştırmaları Dergisi (E-İnternational Journal Of Educational Research), 3(2), 13-35. 
Lickona, T. (1991). Educating for character: How school can teach respect and responsibility. New York: Bantam.

MEB, (2007). Bilim ve sanat merkezleri yönergesi. http://orgm.meb.gov.tr/meb_ iys_dosyalar/2015_08/27014859_bilsemynerge.pdf. Erişim: 29 Ekim 2015.

Özden, Y. (2013). Eğitimde yeni değerler. Ankara: Pegem Akademi.

Rokeach, M. (1973). The nature of human values. Contemporary Sociology, 5(1), 13-16.

Ryan, K., \& Bohlin, K. E. (1999). Building character in schools. San Francisco: Josey-Bass Publishers.

Sarı, E. (2005). Öğretmen adaylarının değer tercihleri: Giresun Eğitim Fakültesi örneği. Değerler Eğitimi Dergisi, 3(10), 73-88.

Schwartz, S. H. (1992). Universals in the content and structure of values: Theory and empirical tests in 20 countries. Advances In Experimental Social Psychology, 25, 1-65.

Schwartz, S.H. \& W. Bilsky. (1987). Towards a psychological structure of human values. Journal Of Personality And Social Psychology. 53, 550-562.

Schwartz, S. H. \& Boehnke, K. (2004). Evaluating the structure of human values with confirmatory factor analysis. Journal Of Research In Personality, 38, $230-255$.

Sığrı, Ü., Tabak, A. \&Ercan, Ü. (2009). Kültürel değerlerin yönetsel kapsamda analizi: Türk bankacılık sektörü uygulaması. Organizasyon ve Yönetim Bilimleri Dergisi, 1(2), 1-14.

Spranger, E. (1928) Types of men. Halle: Max Neimeyer.

Şahin-Fırat, N. (2010). Okul müdürü ve öğretmenlerin okul kültürü ile değer sistemlerine ilişkin algıları. Ĕgitim ve Bilim, 35(156), 71-83.

Tanıt, T. (2007). Ĕgitim yöneticilerinin değer tercihleri ile yaratıcılıkları arasındaki ilişkinin incelenmesi. Yayımlanmamış yüksek lisans tezi. Yeditepe Üniversitesi Sosyal Bilimler Enstitüsü.

Taş, A. M., \& Yeşiltaş, P. D. (2016). Okul Müdürlerinin değer ve değer kazanımına ilişkin görüşleri. Hitit Üniversitesi Sosyal Bilimler Enstitüsü Dergisi, 9(2), 1125-1146.

Turgut, T. (1998). “Örgütsel davranışta değerlerin yeri”, Endüstri ve Örgüt Psikolojisi, II.Ed.: Suna Tevrüz, Türk Psikologlar Derneği Yayınları: Ankara.

Uncu, Ü. (2008). Öğretmen ve eğitim yöneticilerinin değer yönelimlerinin çok boyutlu olarak incelenmesi (İstanbul ili örneği). Yayımlanmamış yüksek lisans tezi, Yeditepe Üniversitesi Sosyal Bilimler Enstitüsü. 
Özge Ceylan, Güven Mildiz

Yavuz, M., Dilmaç, B., \& Derinbay, D. (2015). Okul yöneticilerinin ve öğretmenlerin sahip oldukları değerlerin demografik özellikleri açısından değerlendirilmesi. Değerler Ĕ̈itimi Dergisi, 13(29), 561-583.

Yılmaz, E. (2009). Öğretmenlerin değer tercihlerinin bazı değişkenler açısından incelenmesi. Değerler Eğitimi Dergisi, 7(17), 109-128. 
Extended Abstract

\title{
Evaluation of Value Preferences of Managers and Teachers Working in Science and Art Centers in Terms of Different Variables
}

\author{
Özge CEYLAN, Corresponding Author. Teacher, PhD Student. \\ Kartal Science and Art Center, Ylldız Technical University, Faculty of Education, Science \\ Education Department. \\ E-mail: ozgeceylan86@gmail.com \\ ORCID: 0000-0003-3737-8579
}

Güven YILDIZ, Teacher.

Kartal Science and Art Center.

E-mail: guvenyildiz99@hotmail.com

ORCID: 0000-0001-7075-9838

\section{Introduction}

When we look at the development of mankind throughout history, it seems that humans first tried to satisfy physical needs for survival such as; hunger, marriage and self-defense, then tried to continue the generation and made progress in all areas to live in better conditions. With the aim of living in a better condition, the next generation not only left with physical environment but also with a cultural heritage. Each society has its own economic, social and cultural structure and values that include these structures. Spranger (1928) classified the individuals' values as social, economic, scientific, aesthetic, religious and political. For a better society in which individuals can live in peace and integrity, they must acquire a number of values at a reasonable level in their lives and exhibit those values in their behavior and attitudes. The training of the individuals to ensure the continuity of social life can be defined as the reason that the schools have 
existed as well as it is their official duties (Ekşi, 2003; Lickona, 1991; Ryan ve Bohin, 1991). For this purpose, the notion of values education emerges when all kinds of cultural and basic universal values created and accumulated by the ancestors are taught. A value-free education is unthinkable (Taş ve Yeşiltaş, 2016). Aktay and Ekşi (2009) stated that school administrators and teachers share the responsibility for the values, education policies and philosophy to be given, and they are responsible for realizing these policies through programs. First, all managers and teachers should be the role models, establish the conditions of appropriate values education, supervisors should supervise the teachers in order to comply with the program and they should cooperate with the parents in order to provide the basic values (Boydak Özan, 2009; Balyer, 2012; Özden, 2013). Values can be seen by managers as one of the more powerful tools for shaping the big picture, developing an integrative vision and goals, and providing leadership to their organization (Yavuz, Dilmaç ve Derinbay, 2015).

Values start with the pre-school period and take place directly or indirectly in the curriculum during primary and secondary education. Gifted individuals are defined as a potential that will give direction to society and have the ability to make the country strong in technological, political, economic and scientific sense (MEB, 2007). Children with these characteristics will be a great gain for humanity, and they can be a great loss for society if their education is ignored and their potential is not taken into consideration (Kuzu ve Şenol, 2012). In the study conducted by Beldağ and Keskin (2016), half of the teachers interviewed stated that the education programs applied in science and art centers were effective in gaining values, while the other half stated that they were not effective. For this reason, besides the contributions of special talented individuals to the development of the community in every field, the values they possess are also important. Individuals with special talents are trained in science and art centers (BİLSEM) in our country. In the 2018-2019 academic year, approximately 42,000 students, who have been identified as having special abilities, are trained by BILSEM in 81 provinces. Managers and teachers working in the BILSEM are assigned according to various criteria related to their competence to meet the needs of special talented children. It is expected that teachers and administrators working in these institutions are expected to be academically competent and cognitively advanced. Even though teachers do not see values teaching as part of their role; students are absolutely influenced by the value judgments of their teachers (Halstead \& Taylor, 2000). At the same time, it has become important that managers and teachers have various values and then transfer the values to the students as role models and through education. Considering that 
the relationships arising from the values adopted by BILSEM educators may affect the management policies of the institutions, it is thought that the value preferences of BILSEM teachers and managers that put forward in the research, will benefit the policy determination in the field of special education, help the efficient use of resources and the establishment of the corporate culture.

The problem of the research was determined as "What is the relationship between value preferences and demographic characteristics of administrators and teachers working in science and art centers?".

\section{Aim of the Research}

The purpose of this study is to determine the value judgments of managers and teachers who work in BİLSEM. The Schwartz Value Scale was used for this purpose. It is expected that special talented individuals with an important potential in the development of the country should have competence in the field of values as well as academic knowledge. This study, which aims to reveal whether the educators who train these individuals have these values. Previous research has examined the value judgments of managers and teachers in higher education, secondary education, basic education and pre-school level, but the value judgments of managers and teachers working in science and art centers, which are different educational programs, have not been examined.

\section{Method}

The relational screening model was used as a model. Schwartz Value Scale (SVS) and Personal Information Form were used as data collection tools. The Schwartz Value Scale was developed by Schwartz in 1992 and adapted to Turkish by Kuşdil and Kağıtçıbaşı (2000). The working group of the study consisted of 433 teachers and 105 managers $(\mathrm{N}=538)$ who working in the BILSEM's. Analysis of the data was made with the 23rd version of SPSS package program. T-test and ANOVA were conducted to examine the differences in the demographic characteristics of the main value groups in the Schwartz Value Scale of managers and teachers.

\section{Findings, Conclusion and Recomendations}

Schwartz and Bilsky (1987) value list based on Rokeach's (1973) value list constitute the basis of the Schwartz (1992) value approach. The results of the study were discussed on the basis of Schwartz value approach. 
According to the results of the analysis, the mean scores of the sub-dimensions in the scale were investigated according to the "sex" variable and differences were found in the tradition subscale between the average scores of BILLSEM female and male educators. According to this result, it can be stated that the values perception of teachers working in science and art centers do not correlate vary much with the sex variable. It is related to the adoption of ideas and lifestyles along with "tradition", socio-cultural structure and religion (Akdeniz, 2018). Sı ğrı, Tabak and Ercan (2009) found that male bankers are dependent on their traditional values. Yavuz, Dilmaç and Derinbay (2015) have reached a similar conclusion in their study with administrators. Y1lmaz's (2009) research with teachers showed that the average score of the universality, benevolence, cohesion and security dimensions of female teachers is different from that of males. Tanıt (2007), İmamoğlu and Aygün-Karakitaboğlu (1999) found that there is no difference between the value sub-dimensions of women and men in their studies, whereas many studies showed that gender factor is effective in value differentiation (Bacanl1, 1999; Demirutku, 2007; Kuzgun and Sevim, 2004; Acar, Y1ldırım and Ergene, 1996).

According to the "task" variable of the average scores of the trainers, there was a difference in the power, self-direction, universalizm and tradition subscales and between the average scores of BILLSEM manager (manager and assistant principal) and teachers. In terms of power and tradition sub-dimensions differentiation is in favor of the managers, whereas in the sub-dimension of the self-direction and universalism the differentiation is in favor of teachers. Teachers value self-direction sub-dimension due to the fact that it is more open to innovative and more independent in thought activities. The fact that the average scores of teachers are higher in the universality sub-dimension can also be interpreted as being individuals who are more understanding, tolerant and observing the goodness comparing to the managers. Yavuz, Dilmaç and Derinbay (2015) and Şahin- Firat (2010) found differentiation in the sub-dimension of hedonism according to the task variable and stated that the average score of the teachers was higher. Aktay and Ekşi (2009) did not find any differentiation in sub-dimensions according to task variable. Uncu (2008) stated that there was no significant difference between the two groups in the study of teachers and administrators, and the most preferred value was universality and least preferred value was power. Considering the reflection of the difference in value preferences of BILSEM teachers and managers on the special talented individuals, it can be interpreted that students will be educated by teachers who think independently, 
tolerant and work for the good of all humanity, but their teachers will work in schools that are managed with a more traditional understanding. This may cause incompatibilities between the teacher and the supervisor, which may affect job performance and professional satisfaction.

In the third sub-problem of the study, there was no relationship between the "age" variables of the mean scores of subscales included in the scale. In this study, it can be explained that there is no difference in value among the age range of the educators working in BILLSEM regarding the difference in values due to age variable. Similarly, Aktay and Ekşi (2009) did not find any differentiation in the sub-dimensions according to the age variable. Firat and Açıkgöz (2012) stated that age variable is an important determinant in success, stimulation and compliance value dimensions, and this is true for success dimension in younger age group, stimulation in age group younger than 40 years and compliance dimension in group more than 40 years.

The differences between science and art center educators according to occupational seniority variable are examined. There was a difference only in the hedonism subscale between the "years of occupational seniority " and the subscale average scores of the trainers. This difference was found to be between those who had less than 5 years of seniority and those who had more than 20 years of seniority, and that the average of points was less than 5 years. The group with low professional experience has higher average score in the dimension of hedonism than the professional experience. This can be explained by the fact that young people find more pleasure in life and have more individual happiness. It can also be explained as the innovative aspects of young people because of the fact that the hedonism sub-dimension is open to innovativeness. Similarly, in a study conducted by Işık and Yıldız (2012), concluded that teachers gave more importance to the basic value of hedonism in the first years of their professional experience. Yavuz, Dilmaç and Derinbay (2015) found differences in the arousal and self-management dimensions of the educators according to their seniority variable and stated that this difference was caused by the group with 10-14 years seniority. Y1lmaz (2009) found that values preferences of the teachers in the dimension of power of the ones who have 1 to 5 years seniority; Aktay (2008) and Tanit (2007) found no difference in the value preference dimensions of teachers and administrators according to the seniority variable.

Finally, when the subscale average scores of the "graduation grade" variables of the educators are compared with each other, differences in the hedonism and 
tradition sub-dimensions have emerged. This difference was found among those with undergraduate and graduate degrees and the result was in favored of those with a bachelor's degree. It can be interpreted from the BILSEM educators that the degree of hedonism and traditionality subscale scores of those who have undergraduate degrees are higher than those in lower education level in the teaching profession, but they also give more importance to personal happiness unexpectedly. It is an issue that should be examined whether the educators move away from the traditional structure as their academic levels increase. Besides, it is an important result that the degree of graduation affects their value preferences. Aktay and Ekşi (2009) found no differentiation in the sub-dimensions of power, hedonism, success, arousal, tradition according to their education lev$\mathrm{el}$, but they suggested that they differed in the sub-dimensions of self-control, universality, benevolence, harmony and security. Yavuz, Dilmaç and Derinbay (2015) stated that the values of school principals differ in terms of power, arousal and security according to their educational status, but the average of principals with bachelor degree is higher than those with associate degree.

Suggestions for future research can be listed as follows;

- In the research, differences have emerged between the value preferences of the managers and teachers. A value education seminar or in-service training can be organized for BILSEM managers and teachers, taking into account the needs of the students, in order to minimize the value differences in the studies.

- The research was conducted on specific demographic characteristics. In addition to these, it can be re-interpreted by adding different characteristics such as marital status, income level, having children or in which culture. Many researches state that culture is effective in the value choices of marital status, and this situation can be observed in BILSEM educators.

- In the research the most difference in value has emerged between managers and teachers. In order to minimize this situation, first of all, the thoughts of teachers or principals related to their aims/goals in working in BILSEM can be determined by a qualitative study, and then these goals can be integrated with values in a common denominator and given to both managers and teachers. 